\title{
Desain Tracker Untuk Pemasangan Oil Seal Shock Absorber Depan
}

\section{Studi Kasus Motor Yamaha Byson}

\author{
Rohmana \\ Fakultas Teknik, Teknik Industri \\ Universitas Langlangbuana \\ Jl. Karapitan 116, Bandung \\ anamhor@gmail.com
}

\begin{abstract}
Abstrak - Apresiasi masyarakat Indonesia terhadap perkembangan, pertumbuhan, dan kebutuhan akan sepeda motor semakin meningkat. Hal itu terbukti dengan melihat kondisi kehidupan masyarakat Indonesia sekarang ini. Untuk meningkatkan pelayanan terhadap konsumen maka kinerja teknisi menjadi peranan penting untuk memberi suatu kepuasan terhadap konsumen. Selain pelayanan yang baik, pekerjaan cepat, dan kualitas kerja yang memuaskan. Namun ada pekerjaan yang mengalami keterlambatan dalam melakukan perbaikan, salah satunya adalah pekerjaan dalam penggantian Oil Seal Shock Absorber depan pada Motor Yamaha Byson, disebabkan belum tersedianya alat khusus atau disebut juga special service tool (sst) untuk penggantian tersebut. Sehingga diperlukan rancangan alat bantu saat penggantian Oil Seal Shock Absorber agar waktu proses pemasangan Oil Seal Shock Absorber lebih cepat. Untuk memecahkan masalah ini diperlukan suatu metoda Brainstorming, Sinectics, Enlarging the search space, dan pendekatan rasional. Sehingga ada perubahan dari metode pemasangan lama ke metode baru mengalami peningkatan produktivitas tiap minggu khususnya untuk pekerjaan penggantian Oil Seal Shock Absorber yaitu sebesar $74.33 \%$ untuk metoda baru atau 0.43 jam, dan metode lama $21.52 \%$, atau $1.47 \mathrm{jam}$.
\end{abstract}

Kata kunci - Desain, Oil Seal, Yamaha Byson

\section{PENDAHULUAN}

Dealer resmi dibawah naungan PT. Yamaha Indonesia yang bergerak di bidang retail otomotif khususnya jasa dan penjualan kendaraan motor merk Yamaha dengan status 3S (Sales, Service dan Sparepart). Selain penjualan unit motor dan penjualan sparepart. Service merupakan kegiatan yang penting dalam perusahaan, Service merupakan salah satu persoalan perusahaan yang mempunyai peranan penting dalam memenuhi kebutuhan konsumen dan bagaimana menjadikan konsumen loyal terhadap perusahaan.

Maka kinerja teknisi menjadi peranan penting untuk memberi suatu kepuasan terhadap konsumen. pekerjaan yang mengalami keterlambatan dalam melakukan perbaikan, salah satunya adalah pekerjaan dalam penggantian Oil Seal Shock Absorber depan pada Motor Yamaha Byson. Hal ini disebabkan belum tersedianya alat khusus atau disebut juga special service tool (sst) untuk penggantian tersebut. Pada jenis motor Byson ini berbeda dengan jenis motor pada umumnya, yaitu pada saat pemasangan Oil Seal membutuhkan alat khusus atau tracker. Sementara saat ini pihak Yamaha belum mempunyai alat tersebut. Saat ini Pemasangan Oil Seal dengan cara manual dan memerlukan waktu yang cukup lama dan cukup sulit, karena tingkat resiko tinggi yang dapat mengakibatkan kerusakan pada komponen lain.

Maka pokok permasalahan yang dihadapi adalah bagaimana membuat desain alat bantu saat penggantian Oil Seal Shock Absorber agar waktu proses pemasangan Oil Seal Shock Absorber lebih cepat dan aman.

Tujuan dari penelitian ini adalah: (1) Mengaplikasikan metode perancangan berbasis fungsional pada perancangan alat bantu pemasangan Oil Seal Shock Absorber depan Motor Yamaha Byson; (2) Menghitung waktu baku dan produktivitas kerja alat bantu baru untuk pemasangan Oil Seal Shock Absorber Motor Yamaha Byson. 
Manfaat penelitian ini adalah: (1) Mengurangi keluhan-keluhan teknisi akibat proses kerja dengan menggunakan fasilitas yang kurang baik, memberikan kepuasan terhadap konsumen; (2) Mempermudah teknisi dalam melakukan pekerjaan tersebut dan waktu pemasangan lebih cepat dan sebagai bahan pertimbangan untuk meningkatkan produktivitas dan efisiensi bagi perusahaan.

\section{METODE}

Metode perancangan yang dikenal saat ini adalah metode kreatif dan metode rasional. Metode kreatif adalah metode yang membantu atau membangun rangsangan fikiran-fikiran kreatif. Secara umumdalam metode ini mengungkapkan sebanyakbanyaknya ide dengan menghilangkan hambatanhambatan mental yang menghalangi proses kreatifitas atau dengan kata lain mencari seluasluasnya solusi yang bisa dibuat. Terdapat tiga metode yang termasuk dalam katagori ini, yaitu [1]:

1. Brainstorming, adalah metode yang mengedepankan curahan ide-ide dalam jumlah besar dengan menghilangkan hambatanhambatan mental yang menghalangi proses kreatif.

2. Sinectics, adalah metode yang menggunakan pemikiran analogis yang bertujuan mengumpulkan solusi-solusi kreatif dari tiap-tiap bagian untuk memecahkan masalah yang ada. Dibandingkan dengan brainstorming, Sinectics lebih banyak memerlukan waktu dan faktorfaktor lain.

3. Enlarging the search space, adalah metode yang digunakan untuk membantu menemukan solusi dengan cara memperluas batas-batas pencari solusi.

4. Metode Rasional adalah metode parancangan yang dilakukan dengan memberikan pendekatanpendekatan sistematis dan rasional, sehingga metode ini lebih baik dibandingkan metode kreatif.

\subsection{Quality Function Deployment}

Metode QFD (Quality Function Deployment) [3] merupakan metode yng berfungsi sebagai alat untuk mentransformasikan informasi-informasi tentang keinginan dan kebutuhan konsumen (Customer Needs) [4] kedalam matriks variabel pada penentuan spesifikasi produk atau jasa yang akan dirancang. Menurut Cohen [5] dalam Susiadri [7], QFD adalah metodologi terstruktur yang digunakan dalam proses perancangan dan pengembangan produk untuk menetapkan spesifikasi kebutuhan dan keinginan konsumen, serta mengevaluasi secara sistematis kapabilitas produk atau jasa dalam memenuhu kebutuhan dan keinginan konsumen.
Manfaat utama dari QFD dalam perancangan dan pengembangan produk dan jasa [2][6] adalah sebagai berikut:

1. Memusatkan rancangan produk dan jasa pada kebutuhan pelanggan. Memastikan bahwa kebutuhan konsumen dipahami dan proses desain didorong oleh kebutuhan pelanggan yang objektif dari teknologi.

2. Mengutamakan kegiatan-kegiatan desain. Hal ini memastikan bahwa proses desain dipusatkan pada kebutuhan pelanggan yang paling berarti.

3. Menganalisis kinerja produk perusahaan yang utama untuk memenuhi kebutuhan para pelanggan utama.

4. Dengan berfokus pada upaya rancangan, hal tersebut akan mengurangi lamanya waktu yang diperlukan untuk daur rancangan secara keseluruhan sehingga dapat mengurangi waktu untuk memasarkan produk-produk baru.

5. Mengurangi banyaknya perubahan desain setelah dikeluarkan dengan memastikan upaya difokuskan pada tahap perencanaan. Hal ini penting untuk mengurangi biaya mengenalkan desai baru.

6. Mendorong terselengaranya tim kerja dan menghancurkan rintangan antar bagian dengan melibatkan pemasaran, rekayasa teknik dan pabrikasi sejak awal proyek. Menyediakan suatu cara untuk membuat dokumentasi proses dan menyediakan suatu dasar yang kukuh untuk mengambil keputusan rancangan.

Tujuan dari Quality Function Deployment tidak hanya memenuhi sebanyak mungkin harapan pelanggan, tapi juga berusaha melampaui harapanharapan pelanggan sebagai cara untuk berkompetensi dengan saingannya, sehingga diharapkan konsumen tidak menolak dan tidak komplain, tapi malah menginginkannya. Implementasi QFD terdiri dari tiga tahap, dimana seluruh kegiatan yang dilakukan pada masingmasing tahapan dapat diterapkan seperti layaknya suatu proyek, dengan terlebih dahulu dilakukan tahap perencanaan dan persiapan, ketiga tahapan tersebut adalah [7] :

\section{Tahap pengumpulan suara pelanggan (Voice of Customer)}

2. Tahap penyusunan rumah kualitas (House of
Quality)

3. Tahap analisis dan implementasi 


\subsection{Pengumpulan Suara Pelanggan (Voice of Customer)}

Tahap ini dilakukan survey untuk memperoleh suara pelanggan yang tentu akan memakan waktu dan membutuhkan keterampilan mendengarkan. Proses QFD membutuhkan data pelanggan yang ditulis sebagai atribut-atribut dari produk atau jasa. Atribut bagi pelanggan dan tingkat performasi kepuasan pelangga dari produk yang mirip berdasarkan atribut tersebut. Atribut ini biasanya disebut data pelanggan kualitatif dan informasi numerik tiap atribut sebagai data kualitatif.

\subsection{Menyusun Rumah Kualitas}

Penerapan metode Quality Function Deployment dalam prose perancangan produk diawali dengan pembentukan matriks perencanaan produk atau sering disebut sebagai House of Quality (rumah kualitas). Tahap-tahap dalam menyusun rumah kualitas adalah sebagai berikut [2]:

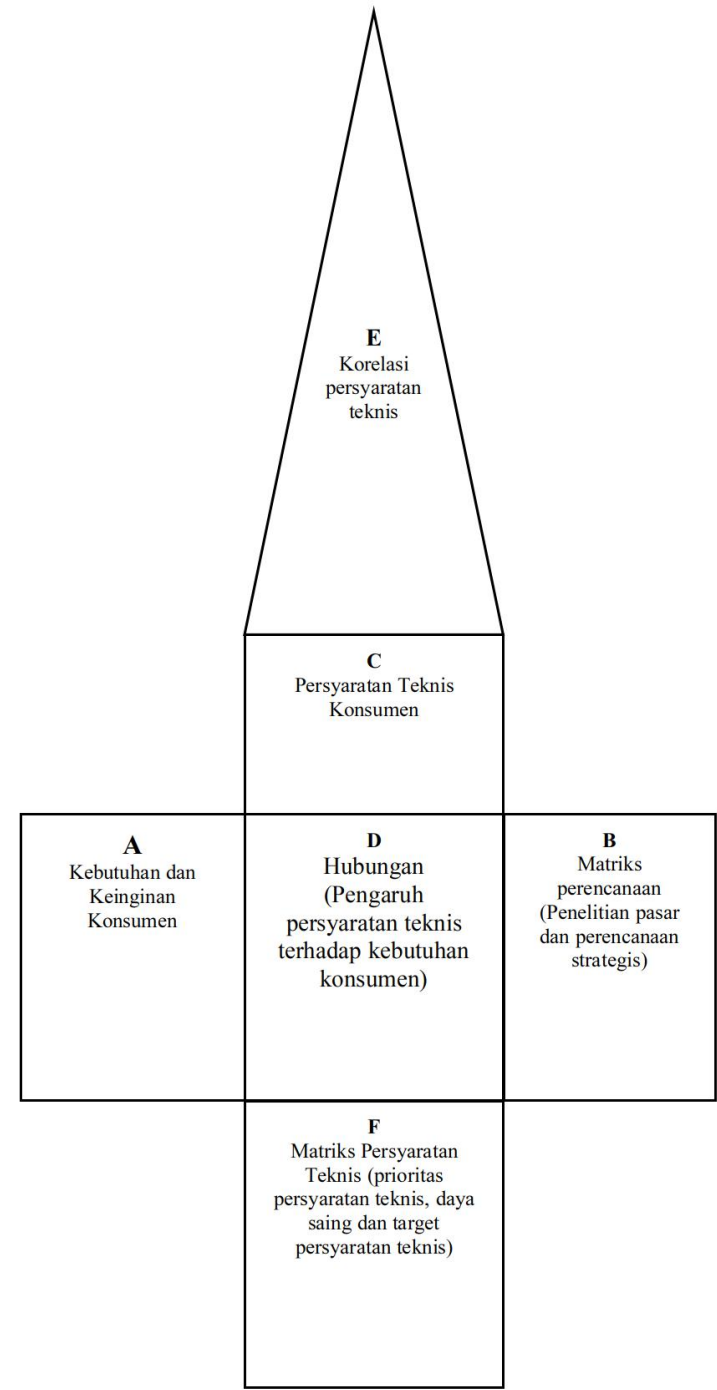

Gambar 1. Struktur House Of Quality (HOQ)

\subsection{Kualitas Produk}

Kualitas produk sangat menentukan posisi perusahaan dimata konsumen, oleh karena itu konsep kualitas harus dimengerti secara tepat oleh perusahaan. Kualitas adalah kemampuan produk dalam melakukan fungsinya selama jangka waktu penggunaan tertentu yang telah ditetapkan [2]. Kualitas adalah karakteristik total suatu entitas yang sesuai dengan kebutuhan dan keinginan konsumen [7].

\subsection{Pengetahuan Bahan Industri}

Sifat-sifat khas bahan industri perlu dikenal secara baik karena bahan tersebut diperguankan untuk berbagai macam keperluan dlam berbagai keadaan. Sifat-sifat bahan yang diinginkan sangat banyak, termasuk: sifat-sifat mekanik (kekuatan, kekerasan, kekakuan, keuletan, keliatan, kepekaan tarikan atau kekuatan impek dsb), sifat-sifat listrik (hantaran listrik elektrisitas, dsb), sifat-sifat magnet (permeabilitas, koersivitas, histrisis, dsb), sifat-sifat termal (panas jenis, pemuaian, konduktifitas, dsb), sifat-sifat kimia (reaksi kimia, kombinasi, segregasi, ketahanan korosi, dsb), sifat-sifat fisik (ukuran,masa jenis, struktur, dsb), sifat-sifat teknologi (mampu mesin, mampu keras, dsb). Evaluasi pengujian sifatsifat mekanik antara lain:

\section{Kekerasan}

Pengujian yang banyak dilakukan adalah dengan menekan penekan tertentu kepada benda uji dengan beban tertentu dan dengan mengukur bekas penekanan yang terbentuk diatasnya atau dengan cara menjatuhkan bola dengan ukuran tertentu dari ketinggian tertentu diatas benda uji dan diperoleh data pantulannya

2. Melar

Adalah kondisi dimana terdapat deformasi secara terus-menerus dan perlahan-lahan dalam kurun waktu yang lama apabila dibebani secara tetap. Dapat terjadi dalam temperatur rendah ataupun mendekati titik cair. Laju melar yang diperbolehkan dalam dunia industri adalah $10^{-7}$ $-10^{-4} \%$ / jam atau $10^{-5}-10^{-2 \%} / \mathrm{jam}$.

3. Kelelahan

Patahan lelah disebabkan oleh tegangan berulang dan juga dijumpai pada tegangan kurang dari 1/3 kekuatan tarik statis pada bahan struktur tanpa konsentrasi tegangan.

4. Keausan

Diakibatkan karena terjadinya friksi pada bidang kontak yang selanjutnya berkembang menjadi parah sampai pada satu saat komponen mesin kehilangan fungsinya dan patah. 
5. Pengaruh lingkungan pada kekuatan dan patahnya bahan

Lingkungan yang bersifat korosi memberikan pengaruh besar pada patahnya dan mengurangi kekuatan putus. Korosi merupakan proses yang lama, yang tidak begitu efektif pengaruhnya pada kekuatan dalam waktu singkat, seperti kekuatan tarik tetapi lebih berpengaruh pada kekuatan kelelahan dan kekuatan melar.

\subsection{Oil Seal}

Oil Seal adalah komponen pada suatu benda yang bergerak berfungsi menyekat pelumas. Pelumas digunakan pada tempat-tempat dimana terjadi gesekan, dan untuk memastikan pergerakkannya menjadi halus dan umurnya menjadi panjang, Oil Seal digunakan untuk mencegah terjadinya kebocoran pelumas yang lewat melalui "Inner Tube" pada bagian yang bergerak tersebut.

\subsection{Analisis Waktu Kerja}

Analisi waktu kerja adalah suatu teknik untuk menentukan isi kerja (work content) suatu tugas atau operasi dengan jalan menetapkan waktu yang diperlukan untuk melakukannya berdasarkan patokan pelaksanaan oleh seoarang pekerja yang cakap. Analisis kerja bertujuan untuk menyelidiki dan mengurangi waktu yang tidak efektif, untuk itu diperlukan pengukuran waktu kerja dan ditetapkan waktu baku (standar).

\subsubsection{Langkah - Langkah Sebelum Melakukan Pengukuran}

Untuk mendapatkan hasil yang bisa dipertanggung jawabkan dengan baik, maka pengukuran tidak cukup dilakukan satu kali. Faktor yang harus diperhatikan agar didapatkan waktu yang sesuai dan pantas untuk pekerjaan yang bersangkutan antara lain:

\section{Kondisi kerja \\ 2. Kondisi Mekanik \\ 3. Cara pengukuran}

\subsubsection{Menetapkan Tujuan Pengukuran}

Seperti halnya dibeberapa kegiatan lain tujuan melakukan pengukuran harus ditetapkan terlebih dahulu. Dalam pengukuran waktu hal-hal penting yang harus ditetapkan adalah untuk apa hasil pengukuran digunakan, beberapa tingkat ketelitan dan tingkat keyakinan yang diinginkan dari hasil pengukuran tersebut.

\subsubsection{Melakukan Penelitian Pendahuluan}

Tujuan dari pengukuran waktu adalah untuk menentukan waktu yang pantas diberikan kepada pekerja untuk menyelesaikan suatu pekerjaan pada kondisi tertentu. Suatu perusahaan biasanya menginginkan waktu kerja yang sesingkatsingkatnya untuk memperoleh keuntungan yang lebih besar. Keuntungan demikian tidak akan diperoleh jika kondisi kerja yang ada tidak menunjang. Waktu yang pantas untuk kondisi ini bisa dicari akan tetapi dapat diduga bahwa itu bukanlah waktu yang sebaik-baiknya melainkan waktu yang lebih lama dari seharusnya.

\subsubsection{Menentukan Jumlah Pengamatan}

Dalam pengambilan sampel untuk menentukan jumlah pengamatan yang diperlukan penulis menggunakan tabel pengamatan (Buku Metoda Penelitian Survai, penerbit LP3ES 1985), adalah sebagai berikut:

1. Ambil pengamatan pendahuluan sebanyak sepuluh kali apabila pekerjaan yang diamati mempunyai selang waktu penyelesaian dua menit atau kurang.

2. Ambil pengamatan ssebanyak lima kaliapabila pekerjaan yang diamati mempunyai selang waktu penyelesaian lebih dari dua menit.

3. Hitung sebaran $(\mathrm{R})$ dengan cara :

$$
\begin{aligned}
& \mathbf{R}=\mathbf{H}-\mathbf{L} \\
& \mathrm{H}=\text { Waktu pengamatan terbesar } \\
& \mathrm{L}=\text { Waktu pengamatan terkecil } \\
& \text { a. Hitung rata-rata waktu } \\
& \text { pengamatan }(\bar{X}) \text { dengan cara : } \\
& \bar{X}=\frac{\Sigma X}{N} \\
& \sum \mathrm{X}=\text { Jumlah waktu yang diamati } \\
& \mathrm{N}=\text { Jumlah frekuensi pengamatan } \\
& \text { b. Hitung sebaran dibagi rata-rata } \\
& \frac{R}{\bar{X}} \\
& \text { Menghitung rata-rata waktu } \\
& \text { penyelesaian benda kerja atau } \\
& \text { pekerjaan dapat dilakukan } \\
& \text { perhitungan secara statistic } \\
& \text { seperti berikut. } \\
& \overline{\bar{X}}=\frac{\sum X}{n} \\
& X=\text { Harga rata-rata sub group } \\
& \mathrm{n}=\text { Jumlah sub group } \\
& \text { Selanjutnya untuk setandar } \\
& \text { deviasi menggunakan rumus } \\
& \text { sebagai berikut : } \\
& \sigma=\sqrt{\frac{\sum(X j-\overline{\bar{X}})^{2}}{N-1}} \\
& \sigma=\text { Standar Deviasi } \\
& \mathrm{N} \text { = Jumlah pengamatan } \\
& \mathrm{Xj}=\text { Waktu penyelesaian pengamatan }
\end{aligned}
$$


Kemudian untuk standar deviasi dari distribusi harga waktu rata-rata menggunakan rumus sebagai berikut :

$$
\begin{aligned}
& \sigma \bar{X}=\frac{\sigma}{\sqrt{n}} \\
& \bar{X}=\text { Standar deviasi distribusi harga } \\
& \text { dibagi waktu rata-rata sub group } \\
& \mathrm{n}=\text { Banyaknya sub group } \\
& \text { Setelah menghitung standar deviasi } \\
& \text { distribusi waktu rata-rata, selanjutnya } \\
& \text { menghitung Batas Kontrol Atas (BKA) dan } \\
& \text { Batas Kontrol Bawah (B KB) }
\end{aligned}
$$

$$
\begin{aligned}
& \text { BKA }=\overline{\bar{X}}+3 \sigma x \\
& \text { BKB }=\overline{\bar{X}}-3 \sigma x \\
& \text { BKA }=\text { Batas Kontrol Atas } \\
& \text { BKB }=\text { Batas Kontrol Bawah }
\end{aligned}
$$

Batas kontrol atas dan batas kontrol bawah ini dimaksud untuk menguji keseragaman data-data tersebut. Jika data-data terletak diantara batas kontrol tersebut maka semua data yang ada dapat digunakan untuk menghitung banyaknya pengukuran, untuk tingkat ketelitian dan tingkat keyakinan tertentu.

Pengertian tingkat ketelitian dan tingkat keyakinan dalam pengamatan adalah sebagai berikut :

1. Tingkat ketelitian menunjukan penyimpangan maksimum hasil pengukuran dari aktu penyelesaian sebenarnya.

2. Tingkat keyakinan menunjukan besarnya keyakinan pengukuran bahwa hasil yang diperoleh memenuhi syarat ketelitian tadi dan ini dinyatakan dalam persen.

Tingkat ketelitian 5\% dengan tingkat keyakinan 99\% mempunyai arti bahwa pengukuran membolehkan rata-rata hasil pengukuran menyimpang sejauh 5\% dari rata-rata sebenarnya, dan pengukuran mempunyai keyakinan akan hasil penelitiannya sebesar $99 \%$.

\subsubsection{Perhitungan Waktu Baku}

Waktu baku adalah waktu yang dipergunakan untuk melakukan suatu tugas oleh pekerja rata-rata yang cakap dan terlatih dengan langkah-langkah yang normal. Besarnya waktu baku (standar) dapat diperoleh dengan pengamatan seperti yang telah penulis terangkan sebelumnya. Setelah mendapatkan waktu rata-rata perlu disesuaikan Faktor-faktor seperti performance rating (penilaian waktu pelaksanaan).

\subsubsection{Produktivitas}

Produktifitas adalah keinginan (will) dan upaya (effort) manusia untuk selalu meningkatkan kualitas kehidupan dan penghidupan disegala bidang. Menurut Encyclopedia Britania (1982:27) disebutkan bahwa produktivitas dalam ekonomi berarti rasio dari hasil yang dicapai dengan pengorbanan yang dikeluarkan untuk menghasilkan sesuatu.

Sedangkan menurut formulasi national productivity board (NPB) singapore, dikatakan bahwa produktivitas adalah sikap mental (attitude of mind) yang mempunyai semangat untuk melakukan peningkatan perbaikan.

Perwujudan sikap mental dalam berbagai kegiatan antara lain sebagai berikut :

1. Yang berkaitan dengan diri sendiri dapat dilakukan melalui peningkatan :
a. Pengetahuan
b. Keterampilan
c. Disiplin
d. Upaya pribadi
e. Kerukunan kerja

2. Yang berkaitan dalam pekerjaan,dapat dilakukan melalui :

a. Management dan metoda kerja yang lebih baik.

b. Penghematan biaya.

c. Ketepatan waktu.

d. Sistem dan teknologi yang lebih baik.

Dengan mengadakan perbaikan tersebut, maka diharapkan akan dapat menghasilkan barang dan jasa yang bermutu tinggi dan standar kehidupan yang lebih tinggi. Secara umum produktivitas mengandung pengertian perbandingan antara hasil yang dicapai (output) dengan keseluruhan sumber daya yang digunakan (input).

Tingkat produktivitas yang dicapai merupakan suatu indicator terhadap efisiensi dan kemajuan ekonomi untuk ukuran industri, maupun untuk ukuran pendidikan. Dengan kata lain dapat dikatakan bahwa produktivitas memiliki dua dimensi, yakni efektifitas dan efisiensi. Dimensi pertama berkaitan dengan pencapaian untuk kerja yang maksimal, dalam arti pencapaian target yang berkaitan dengan kualitas, kuantitas dan waktu. sedangkan dimensi kedua berkaitan dengan upaya membandingkan masukan dengan realisasi penggunaanya atau bagaimana pekerjaan tersebut dilaksanakan. 
Efisiensi merupakan suatu ukuran dalam membandingkan penggunaan masukan (input) yang direncanakan dengan penggunaan masukan yang sebenarnya terlaksana. Apabila masukan yang sebenarnya digunakan semakin besar penghematannya, maka tingkat efisiensi semakin tinggi, tetapi semakin kecil masukan yang dihemat, sehingga semakin rendah tingkat efisiensi.

Efektivitas merupakan suatu ukuran yang memberikan gambaran seberapa jauh target dapat dicapai. Pengertian efektivitas ini lebih berorientasi kepada keluaran sedangkan masalah penggunaan masukan kurang menjadi perhatian umum. Apabila efisiensi dikaitkan dengan efektifitas maka walaupun terjadi peningkatan evektivitas belum tentu efisiensi meningkat.

Kualitas merupakan suatu ukuran ya ng menyatakan seberapa jauh telah terpenuhi berbagai persyaratan, spesifikasi, dan harapan. Konsep ini dapat hanya berorientasi kepada masukan, ke;luaran, atau keduanya. Disamping itu kualitas juga berkaitan dengan proses produksi yang akan berpengaruh pada kualitas hasil yang dicapai secara keseluruhan. Secara skematis berkaitan antara efisiensi, efektivitas, kualitas dan produktivitas. Jadi dapat disimpulkan bahwa pengertian produktivitas adalah sebagai berikut :

$$
\text { Produktivitas }=\frac{\text { Ef ektivitas }}{\text { Efisiensi }}
$$

\section{METODE PENELITIAN}

\subsection{Studi Lapangan}

Tahap ini dilakukan dengan terlebih dahulu mempelajari prinsip kerja dari suspensi depan dan Shock Absorber secara keseluruhan terutama pada Oil Seal yang sering terjadi kebocoran.

\subsection{Studi Literatur}

Studi literatur ini bertujuan untuk mendapatkan landasan teori dan konsep yang sesuai untuk mendapatkan landasan-landasan pemikiran yang dapat menunjang pemecahan masalah yang dihadapi. Dalam penelitian ini dilakukan dengan jalan membaca buku-buku yang berkaitan dengan perancangan produk, Quality Function Deployment (QFD), pengetahuan bahan dan jurnal dari penelitian sejenis yang ada kaitannya dengan penelitian ini serta mencari referensi materi pendukung lainnya seperti dari internet.

\subsection{Pengumpulan Data}

Pada tahap ini dilakukan proses pengumpulan data sebagai landasan dalam perancangan alat untuk pemasangan Oil Seal Shock Absorber. Hal tersebut dilakukan dengan mengidentifikasi keinginan pelanggan (teknisi) dengan melakukan diskusi dan wawancara dengan orang yang berkompeten (expert), data-data teknis dan spesifikasi yang dibutuhkan.

\subsection{Pengolahan Data}

Tahap pengolahan data dilakukan dengan mengolah data-data yang telah ada pada tahap pengumpulan data dengan mengacu pada perancangan produk dan analisis waktu. Adapun tahap-tahap tersebut adalah:

a. Klarifikasi Tujuan

Tahap ini dilakukan untuk menentukan perancangan dengan mengacu kebutuhan pemakai (Teknisi). Metoda yang digunakan adalah Pohon Tujuan (Objectives Trees), sehingga dapat mengidentifikasi tujuan dan sub tujuan dari perancangan Tool untuk pemasangan Oil Seal Shock Absorber beserta hubungan keduanya yaitu dalam bentuk diagram yang menunjukan hubungan hierarki antara tujuan dan sub tujuannya.

\section{b. Penetapan Fungsi}

Tahap ini bertujuan untuk menetapkan fungsifungsi yang diperlukan dari produk yang akan dibuat dan juga merupakan batas-batas sistem rancangan alat bantu pemasangan Oil Seal Shock Absorber yang baru. Metode yang digunakan adalah Analisis Fungsi (Analisis Function Method) dengan menggambarkan sistem input-output dari proses pembuatan Tool pemasangan Oil Seal Shock Absorber dengan prinsip Black Box dan kemudian diterjemahkan dalam Transparent Box sehingga sub-sub fungsi dan interaksinya dapat terlihat jelas.

\section{c. Penetapan Kebutuhan}

Tahap penetapan kebutuhan ini merupakan acuan dalam proses perancangan selanjutnya, dimana tahap ini bertujuan untuk membuat spesifikasi pembuatan Tracker untuk pemasangan Oil Seal Shock Absorber yang akurat yang diperlukan pada proses desain atau batasan teknis pada proses desain. Metode yang dipakai Model Spesifikasi Performasi (Performance Specification Model). 
d. Penentuan Karakteristik

Tahap selanjutnya adalah menetapkan karakteristik yang bertujuan untuk mengetahui selera konsumen terhadap produk/alat untuk pemasangan Oil Seal Shock Absorber. Hal ini dilakukan dengan metode Quality Function Deployment (QFD), yaitu menerjemahkan keinginan konsumen kedalam bentuk atributatribut produk yang disesuaikan dengan karakteristik teknis dari perancangan dan kemudian digambarkan dalam matrik House of Quality.

\section{e. Pembuatan Alternatif}

Setelah penentuan karakteristik produk diketahui, dilakukan proses pembangkitan alternatif yang merupakan tahap proses perancangan yang berguna untuk membangkitkan alternatifalternatif yang dapat mencapai solusi terhadap pemecahan permasalahan. Metode yang digunakan adalah Morphological Chart yang didalamnya merupakan kombinasi dari berbagai kemungkinan solusi untuk membuat alat bantu untuk pemasangan Oil Seal Shock Absorber dengan karakteristik teknis yang berbeda dan bervariasi.

\section{f. Evaluasi Alternatif}

Tahap ini merupakan tahap penentuan alternatif terbaik dari berbagai macam alternatif yang muncul untuk perancangan alat bantu untuk pemasangan Oil Seal Shock Absorber ini, sehingga diperoleh satu rancangan yang terbaik yang dapat memenuhi keinginan konsumen. Peningkatan Detail (Improving Details)

Setelah alternatif dipilih, tahap metode rasional yang terakhir adalah peningkatan detail produk yang dilakukan dengan pertimbangan meliputi proses eliminasi, reduksi, penyederhanaan, modifikasi dan standarisasi terhadap alternatif yang terpilih.

\section{HASIL DAN DISKUSI}

\subsection{Mengidentifikasi Hubungan Antara Atribut Produk dengan Karakteristik Teknik}

Pada tahap ini dilakukan dengan menggunakan skor yang tertinggi menunjukan tingkat kemudahan yang paling tinggi bagi tim perancang untuk mengidentifikasi karakteristik teknik yang paling mempengaruhi kepuasan konsumen.

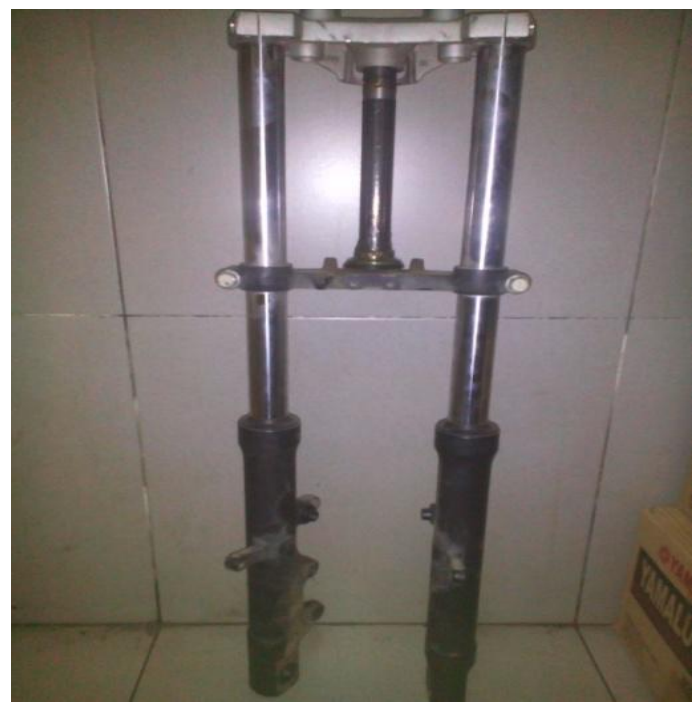

Gambar 2. Shock Absorber Depan Motor Yamaha Byson

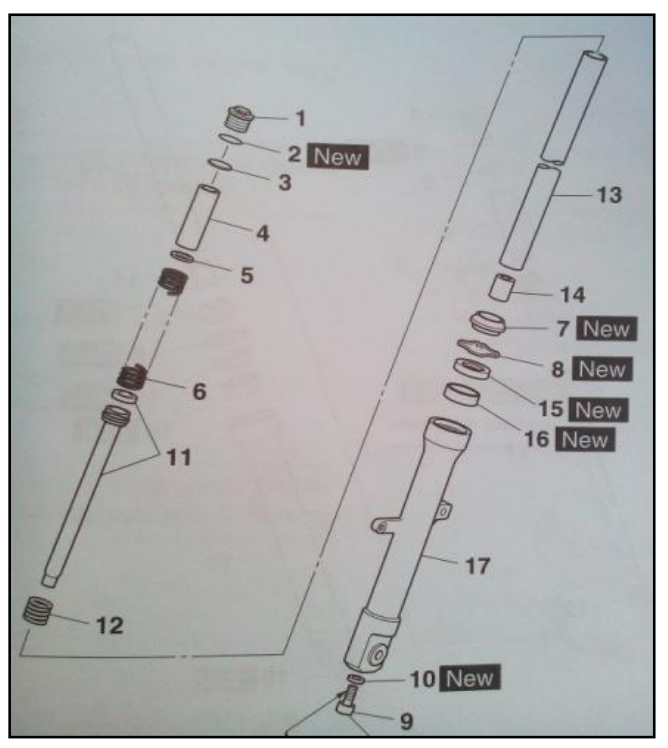

Gambar 3. Shock Absorber Assy Depan Motor Yamaha Byson 
Tabel 1. Matrik Hubungan Atribut Produk dengan Karakteristik Teknik

\begin{tabular}{|c|c|c|c|c|c|c|c|}
\hline & 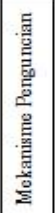 & 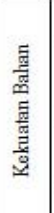 & 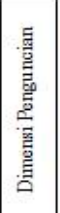 & 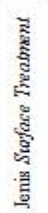 & 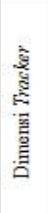 & 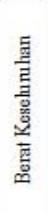 & 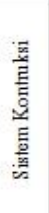 \\
\hline Mudah perawatan & O & & 0 & ○ & & $\Delta$ & O \\
\hline \begin{tabular}{|l} 
Mudah saat asembling \\
\end{tabular} & & O & & & $\Delta$ & 0 & \\
\hline Tahan terhadap korosi & & $\Delta$ & & & & & 0 \\
\hline Tahan lama/awet & $\Delta$ & ○) & & 0 & & & ○ \\
\hline Tampilan bentuk & $\Delta$ & & & & $\mathrm{O}$ & & 0 \\
\hline \begin{tabular}{|l|} 
Aman saat operasional \\
\end{tabular} & 0 & & $\mathrm{O}$ & & & & \\
\hline Mampu menahan tarikan & $\Delta$ & $\circ$ & & & $\mathrm{O}$ & & 0 \\
\hline Bentuk alat (tool) kokoh & & & & & 0 & 0 & 0 \\
\hline Komponen standar (pendukung) & & & & & & $\Delta$ & \\
\hline Bersesuaian dengan komponen lain & & & & & $\mathrm{O}$ & & \\
\hline Digunakan untuk dua jenis pekerjaan & O & & 0 & & 0 & & $\Delta$ \\
\hline $\begin{array}{l}\text { Kecepatan penggantian } \\
\text { Oil Seal ShockAbsorber }\end{array}$ & 0 & & & & & & \\
\hline Kemvdahan dalam pengoperasian & $\mathrm{O}$ & & & & & & \\
\hline $\mid \begin{array}{l}\text { Tenaga minimal saat dioperasikan } \\
\text { a }\end{array}$ & & & & & $\mathrm{O}$ & ○ & $\Delta$ \\
\hline Harga pembuatan relatif murah & & O & & & & & 0 \\
\hline
\end{tabular}

\subsection{Mengidentifikasi Hubungan antara Sesama Karakteristik Teknik}

Langkah ini bertujuan untuk mengidentifikasi hubungan antara sesame karakteristik yang satu dengan yang lainnya, dapat dilihat pada gambar di bawah ini.

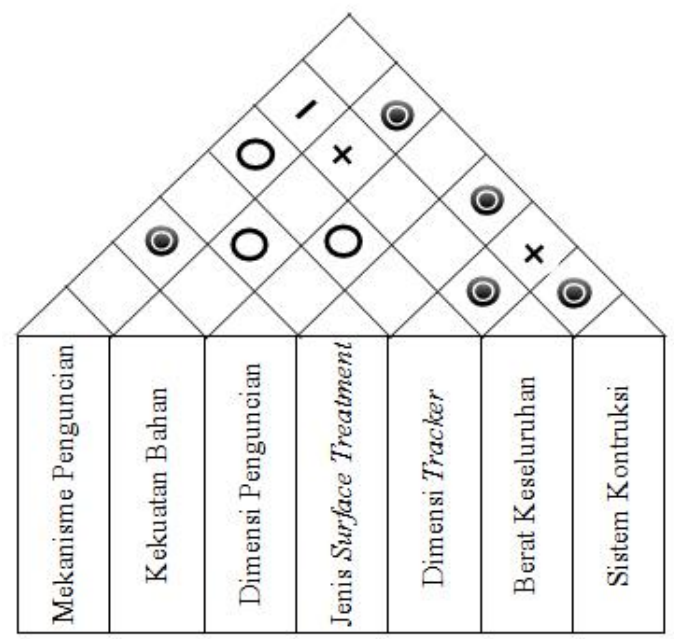

Gambar 4. Hubungan Antara Sesama Karakteristik Teknik

$$
\begin{aligned}
& \text { Keterangan gambar: } \\
& \text { ○) Hubungan positif kuat = } 4 \\
& \mathrm{O}=\text { Hubungan positif }=3 \\
& \text { - = Hubungan negatif }=2 \\
& \mathbf{X}=\text { Hubungan negatif kuat }=1 \\
& =\text { Tidak ada hubungan } \quad=0
\end{aligned}
$$

\subsection{Menentukan Target Pencapaian untuk Setiap Karakteristik Teknik}

Pada langkah ini ditentukan target yang harus dicapai untuk masing-masing karakteristik teknik, tingkat kesulitan pembuatan produk, tingkat kepentingan dan perkiraan biaya tingkat masingmasing karakteristik teknik.

\subsubsection{Tingkat Kesulitan}
a. Mekanisme penguncian $=9 / 66 \times 100 \%=$ $13.6 \%$
b. Kekuatan bahan $=8 / 66 \times 100 \%=12.1 \%$
c. Dimensi pengunci $=7 / 66 \times 100 \%=10.6 \%$
d. Jenis surface treatment $=7 / 66 \times 100 \%=$ $10.6 \%$
e. Dimensi tracker $=11 / 66 \times 100 \%=16.6 \%$
f. Berat keseluruhan $=11 / 66 \times 100 \%=16.6 \%$
g. Sistem kontruksi $=13 / 66 \times 100 \%=19.6 \%$
h. Total bobot $=66$

\subsubsection{Derajat Kepentingan}

a. Mekanisme penguncian $=30 / 171 \times 100 \%=$ $17.5 \%$

b. Kekuatan bahan $=25 / 171 \times 100 \%=14.6 \%$

c. Dimensi pengunci $=9 / 171 \times 100 \%=5.2 \%$

d. Jenis surface treatment $=12 / 171 \times 100 \%=$ $7.0 \%$

e. Dimensi tracker $=31 / 171 \times 100 \%=18.1 \%$

f. Berat keseluruhan $=17 / 171 \times 100 \%=9.9 \%$

g. Sistem kontruksi $=47 / 171 \times 100 \%=7.4 \%$

h. Total bobot $=171$

\subsubsection{Perkiraan Biaya}

a. Mekanisme penguncian $=1 / 7 \times 100 \%=$ $14 \%$

b. Kekuatan bahan $=1 / 7 \times 100 \%=14 \%$

c. Dimensi pengunci $=1 / 7 \times 100 \%=14 \%$

d. Jenis surface treatment $=1 / 7 \times 100 \%=$ $14 \%$

e. Dimensi tracker $=1 / 7 \times 100 \%=14 \%$

f. Berat keseluruhan $=1 / 7 \times 100 \%=$ $14 \%$

g. Sistem kontruksi $=1 / 7 \times 100 \%=14 \%$

h. Total bobot $=7$ 
Tabel 2. Hubungan antara Karakteristtik Teknik dengan Tingkat Kesulitan, Derajat Kepentingan dan Perkiraan Biaya

\begin{tabular}{|c|c|c|c|c|c|c|c|}
\hline & 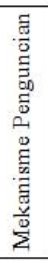 & 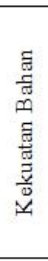 & 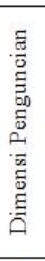 & 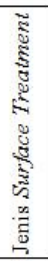 & 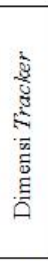 & 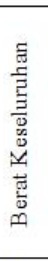 & 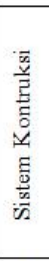 \\
\hline Tingkat Kesulitan & 3 & 1 & 3 & 1 & 3 & 3 & 3 \\
\hline Derajat Kepentingan & 15 & 11 & 3 & 10 & 14 & 8 & 22 \\
\hline Perkiraan Biaya & 14 & 5 & 14 & 14 & 14 & 5 & 14 \\
\hline
\end{tabular}

Hasil dari tabel QFD dalam perancangan alat bantu pemasangan Oil Seal Shock Absorber Yamaha Byson:

a. Mudah perawatan dan mudah saat assembling

b. Tahan terhadap korosi, dan tahan lama

C. Aman pada saat operasional dan mampuh menahan beban

d. Bersesuaian dengan komponen lain

e. Dapat digunakan dua jenis pekerjaan

f. Kecepatan penggantian Oil Seal Shock Absorber

g. Kemudahan dalam pengoperasian

h. Tenaga minimal saat dioperasikan

i. Harga pembuatan relatif murah.

\subsection{Evaluasi Alternatif}

Evaluasi alternatif ini merupakan proses penentuan alternatif terbaik dari kedua alternatif yang muncul, sehingga diperoleh suatu rancangan alat bantu pemasangan Oil Seal Shock Absorber yang baik dan dapat memenuhi keinginan konsumen. Hal ini dilakukan dengan melakukan evaluasi terhadap setiap alternatif dengan konsultasi kepada pihak engineering.

Alternatif terpilih yang dapat memenuhi fungsifungsi yang terdapat pada tracker pemasangan Oil Seal Shock Absorber adalah:

1. Sistem kontruksi yang digunakan adalah sistem pengelasan

2. Bahan tracker menggunakan besi kontruksi

\subsection{Peningkatan Detail Produk (Improving Detail)}

Langkah selanjutnya dari proses perancangan ini adalah tahap peningkatan detail produk yang bertujuan meningkatkan/memperbaiki nilai dari produk yang dibuat untuk mereduksi biaya produksi yang terjadi. Acuan dalam mengurangi biaya adalah:

1 Menghapus, menghilangkan komponen yang mempunyai fungsi sama atau berlebihan

2 Mengurangi, mengeliminasi komponen dengan menggabungkan beberapa komponen menjadi satu
3 Menyederhanakan, membuat alternatif yang paling sederhana

4 Modifikasi, melakukan modifikasi atau merubah metode manufaktur menjadi lebih efisien

5 Standarisasi, membuat atau menggunakan standarisasi komponen

Rancanagan tracker pemasangan Oil Seal Shock Absorber memilki desain yang berbeda dan mempunyai peningkatan fungsi pada bagian tertentu yaitu:

1 Dapat digunakan untuk dua jenis pekerjaan tanpa mengurangi fungsinya

2 Dimensi secara keseluruhan tetap mengacu sesuai jarak yang ada dengan sub assy lainnya, sehingga tidak mengganggu fungsi sub assy yang bersesuaian

3 Tracker pemasangan Oil Seal Shock Absorber dibuat hanya satu set saja teapi mampu digunakan untuk dua jenis pekerjaan yaitu pemasanagan Oil Seal Shock Absorber dan pemasangan Kom Stir. Sehingga terjadi efisien dalam proses manufaktur menjadi lebih sedikit

4 Terjadi kemudahan ketika pemasanagan Oil Seal Shock Absorber, dimana ketika pemasanagan Oil Seal Shock Absorber trus mau digunakan untuk pemasangan kom stir atau pemasangan Oil Seal Shock Absorber tipe lain hanya cukup membuka bantalan yang terpasang dibagian kepala (atas tracker) dan proses penggunaannya sama.

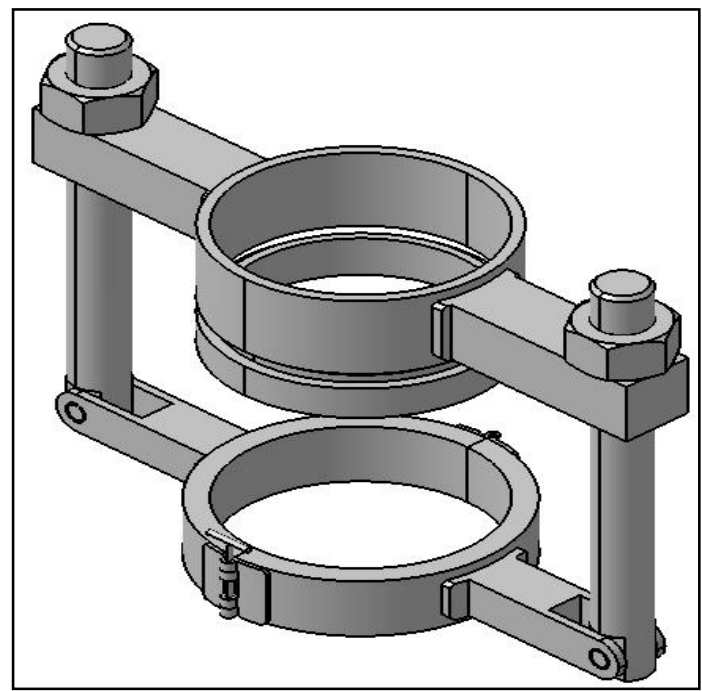

Gambar 5. rancangan Tracker Oil Seal Shock Absorber 


\section{KESIMPULAN}

Kesimpulan yang dapat diambil dari penelitian ini adalah Perancangan ini menggunakan metode berbasis fungsional dengan mempertimbangkan waktu pemasangan Oil Seal Shock Absorber.

Penggunaan alat bantu hasil perancangan ternyata dapat meminimalkan waktu dan kerusakan pada komponen lain.

Dengan metode rasional didapatkan konsep desain yang dapat memenuhi keinginan stakeholder dengan fungsi-fungsi utama yaitu; Sistem kontruksi yang digunakan melalui pengelasan, dan Bahan tracker menggunakan besi ST37

Dengan perubahan metode pemasangan dari metode lama ke metode baru terjadi peningkatan produktivitas tiap minggu khususnya untuk setiap pekerjaan penggantian Oil Seal Shock Absorber yaitu sebasar $52.8 \%$. (Produktivitas metode lama $21.52 \%$, dan metode baru $74.33 \%$ ).

\section{DAFTAR PUSTAKA}

[1] Cross, Nigel, Engineering Design Methods: Strategies for Product Planning, New York: John Wiley and Sons Ltd, 1989

[2] Ginting, Rosnani, Perancangan Produ k, Graha Ilmu Yogyakarta, 2009

[3] Lockyer, K.G, Muhleman, A, Oakland, J, Alih Bahasa: Syahrizal Noor, SE, MBA, Manajemen Produksi Dan Operasi, PT Elek Media Komputindo 1990

[4] Singaribun, Masri, dan Effendi, Sopfian, Metode Penelitian Survai, Penerbit LP3ES, 1985

[5] Sudarmayanti, Dra,M.Pd, Sumber Daya Manusia dan Produktivitas Kerja, Penerbit Ilham Jaya, Bandung Cetakan Pertama, Juni 1995

[6] Sutalaksana, Iftikar Z, Teknik Tata Cara Kerja, Penerbit Laboraturium Tata Cara Kerja \& Ekonomi Departemen Teknik Industri, ITB

[7] Shinroku, S, Surdia, T, Pengetahuan Bahan Teknik, Pradnya Paramita Jakarta, 2000. 